\title{
AUDIO VISUAL MEDIA COMPONENTS IN EDUCATIONAL GAME FOR ELEMENTARY STUDENTS
}

\author{
Meilani Hartono ${ }^{1}$ Andri Guna Santoso ${ }^{2}$; Crisantus Lebu Raya ${ }^{3}$; \\ Budi Yulianto ${ }^{4}$; Suwarno ${ }^{5}$ \\ ${ }^{1,5}$ Primary School Teacher Education Department, Bina Nusantara University, \\ Jln. K.H. Syahdan No 9, Jakarta Barat, DKI Jakarta, 11480, Indonesia; \\ ${ }^{2,3,4}$ Computer Science Department, School of Computer Science, Bina Nusantara University, \\ Jln. K.H. Syahdan No 9, Jakarta Barat, DKI Jakarta, 11480, Indonesia \\ 1'mhartono@binus.edu; ${ }^{2}$ andrigunasantoso@yahoo.com; ${ }^{3}$ chrisantusleburaya@yahoo.com; \\ 4laboratory@binus.ac.id; 5 suwarno001@binus.ac.id
}

\begin{abstract}
The purpose of this research was to review and implement interactive audio visual media used in an educational game to improve elementary students' interest in learning mathematics. The game was developed for desktop platform. The art of the game was set as 2D cartoon art with animation and audio in order to make students more interest. There were four mini games developed based on the researches on mathematics study. Development method used was Multimedia Development Life Cycle (MDLC) that consists of requirement, design, development, testing, and implementation phase. Data collection methods used are questionnaire, literature study, and interview. The conclusion is elementary students interest with educational game that has fun and active (moving) objects, with fast tempo of music, and carefree color like blue. This educational game is hoped to be an alternative teaching tool combined with conventional teaching method.
\end{abstract}

Keywords: audio-visual, educational game, teaching method

\section{INTRODUCTION}

Formally, the time when students learn mathematic lesson for the first time is in primary schools. This moment will give impact for children that might affect their preference and self-efficacy about the subject. Based on Rakhmawati's study (Rakhmawati, 2014), most students assumed that all the lessons related to arithmetic and their complexity are difficult to learn, especially math. Arguably, learning math needs logical, systematic, critical, and problem-solving related abilities. Math is a basic knowledge that is needed by children to improve the percentages of successful learning in the next level education (Amirali, 2010). Therefore, creative methods are needed to present the material to support the ease of learning mathematics.

Children between five to twelve year-old are the main users in using media information and technology (Yogananti, 2015). Many growth of technology such as game has been used for various things positively. Other than as a form of entertainment, it has also become an additional learning method. The use of innovative tools in learning process can potentially increase the willingness and motivation, to learn (Ameliola \& Nugraha, 2015; Chiong, 2010).

Learning is mostly done through literacy, which commonly consisted of writing, reading, and listening. Moreover, learning processes mostly occur in classroom in which communication between teacher and students are established (Rideout et al., 2011). The source of learning that is delivered came from books with full text and few pictures (Suheri, 2006). According to Suheri (2006), students can also have their own self-learning by doing reading and writing in their own time. Students often 
have difficulty to understand the materials that were given in full narration text with disproportionately low number of pictures in the books. As a result, students experience difficulties to memorize or understand the materials. The problem becomes much more noticeable when students are learning subjects which require advanced logical reasoning and problem-solving skills such as science.

Fisch (2005) indentify that a stronger approach will be achieved from putting educational content in the middle of interesting games. Then, children will utilize their learned academic skills and knowledge to play the game. Fisch (2005) also stated that the selection of the right media to provide feedback and a strong foothold both in and outside the game are very important in designing an effective educational game. Educational game is an entertainment application for children to learn school subjects. Learning while playing educational game can improve the knowledge and the studying behavior of students (Yien, 2011). Educational game also enables students to study and have fun at the same time (Liu, 2014).

In an educational game, multimedia components, such as audio, graphics, and animation take an important role (Hamdani, 2011). Hamdani (2011) stated that the benefits from using audio visual media are the learning system becomes more innovative and interactive; the ability to unite between text, images, audio, music, and animation that support each other to achieve the objective of learning; the ability to attract the happiness while the learning process occur, this will potentially increase the students' motivation within teaching and learning processes; the potential to reach audience in big or small scales; being able to visualize the materials that are usually difficult to be explained verbally or with only conventional demonstration; being able to simplify and quicken the teachers to prepare and present study materials; and the ability to store and retrieve media easily.

Previous research also showed that teaching by using multimedia technology had supported learning more interesting and effective, especially for teachers and students (Yuliantu \& Layona, 2015). Students can understand the materials easier and faster, and teachers can deliver the materials in interactive way. Abdullah conducted a research to 160 elementary students that are split into two groups. They were given a mathematic test to see the score before the research. The first group learned mathematic in the conventional way while the second group learned through educational game. After 3 months, they were tested again. The result showed that the second group had a significantly higher improvement in comparison to the first group (Abdullah et al., 2011).

By using computer technology, audio-visual content was adjusted according to the children's favorite colors, images, song tempo, and animation support (Arsyad, 2007). Audio-visual media is expected to present more interesting learning content in educational games. Some educational games are displayed in Figure 1. Through audio-visual media tools, learning content can be more interactive and allow two-way traffic in the learning process (Haryoko, 2012). Audio-visual media is divided into audio (voice \& song) and graphics (pictures and animation).
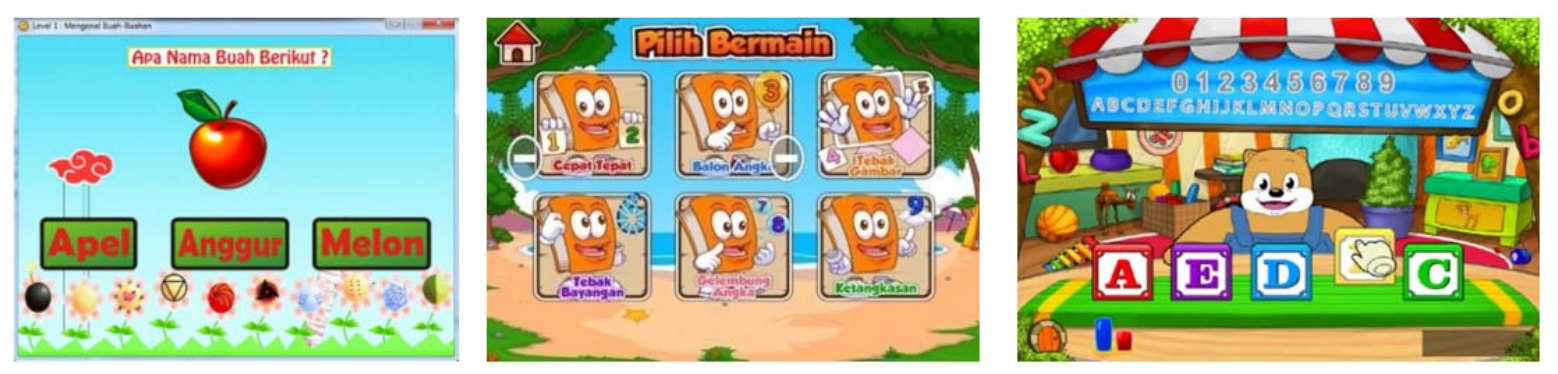

Figure 1 Educational Games Examples: (a) Tebak Gambar,

(b) Marbel: Mari Belajar, and (c) Bobby Bolla 
Animation is a series of images that form a movement. Animation's characteristic that can show movement can be very helpful in explaining the procedure and sequence of events. A similar research conducted by Utami also showed that the effectiveness of animation has so many variations for each level of learning. Comparing animation with static illustrations, animations further enhance the persistence in learning (Utami, 2011). 80\% of students who received learning with animations demonstrated seriousness in learning than those who received learning with static images. On average, $64 \%$ of students in the group of animation get higher grades in examinations related to factual knowledge and applications compared to the students in groups that use static illustrations. Things to be considered in the use of animation is a memory processing capabilities, knowledge of the early disciplines, spatial ability, and how animations were created. Good animation can support students to form a mental picture of the processes that occurs and requires more effort to be learned (Yulianto et al., 2013).

Making a good animation needs a good color combination which supports a good composition to be seen (TigerColor, 2016; Goethe, 1840). The effect of using any color in an animation would have many possibilities such as unsightly or not (Mayer \& Moreno, 2004; Yogananti, 2015). Some schemes of basic color chords based on the color wheel are described as follow (TigerColor, 2016).

Complementary color scheme is colors that are opposite of each other on the color wheel are considered to be complementary colors (example: red and green). The high contrast of complementary colors creates a vibrant look especially when used at full saturation (Figure 2). This color scheme must be managed well so it is not jarring. However, complementary color schemes are tricky to use in large doses, but they can work well when peoples want something to stand out. In addition to that, complementary colors are really bad for text.
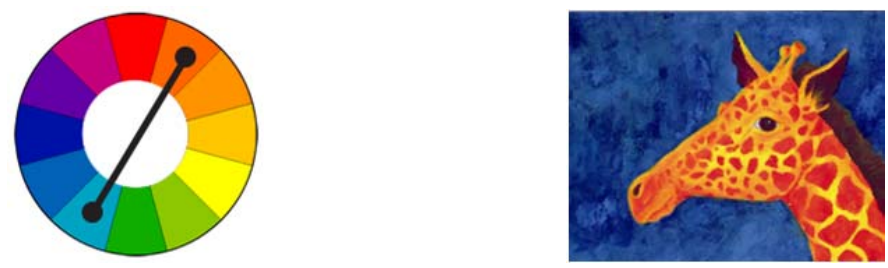

Figure 2 Complementary Color Scheme (TigerColor, 2016)

Analogous color scheme refers to the colors that are next to each other on the color wheel. The colors usually match well and create serene and comfortable designs (Figure 3). Analogous color schemes are harmonious and pleasing to the eye, and they are often found in nature. This is typically achieved by choosing one color to dominate, then a second color to support the former one. The third color is used (along with black, white or gray) as an accent.
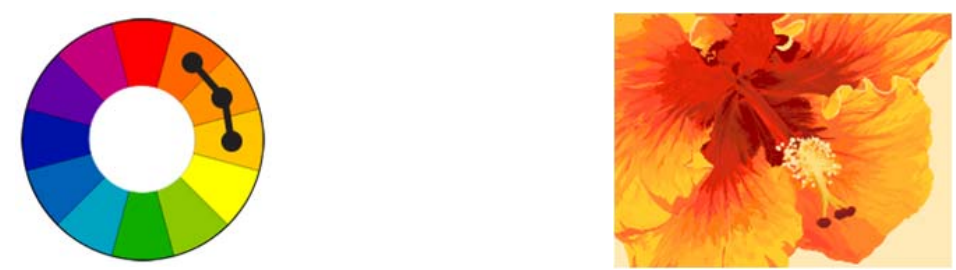

Figure 3 Analogous Color Scheme (TigerColor, 2016) 
Triadic color scheme uses colors that are evenly spaced around the color wheel. Triadic color schemes tend to be quite vibrant, even if it used for pale or unsaturated versions of the hues (Figure 4). To use a triadic harmony successfully, the colors should be carefully balanced - letting one color to dominate and use the two others for accent.
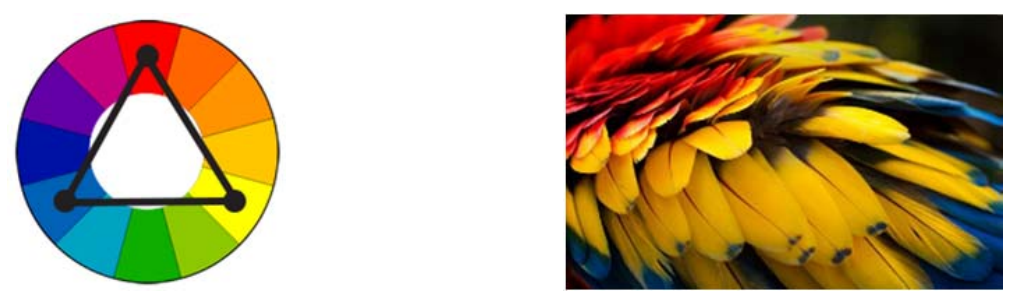

Figure 4 Triadic Color Scheme (TigerColor, 2016)

Split-complementary color scheme is a variation of the complementary color scheme. In addition to the base color, it uses the two colors adjacent to its complement. This color scheme has the same strong visual contrast as the complementary color scheme, but has less tension (Figure 5). The split-complimentary color scheme is often a good choice for beginners, because it is more difficult to be messed up.
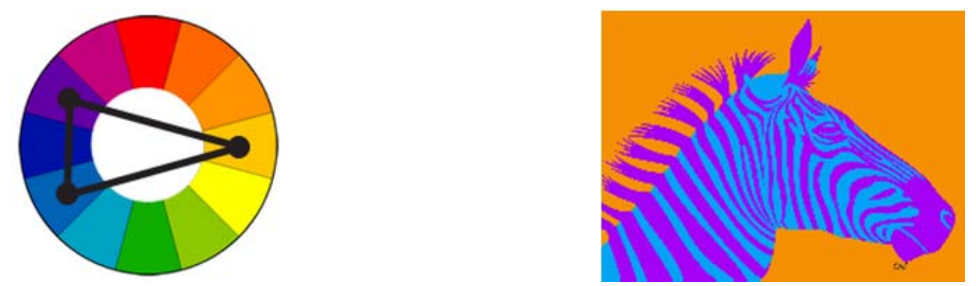

Figure 5 Split-Complementary Color Scheme (TigerColor, 2016)

Rectangle (tetradic) color scheme uses four colors arranged into two complementary pairs. This rich color scheme offers plenty of possibilities for variation (Figure 6). Tetradic color scheme works best when one color is set to be dominant.
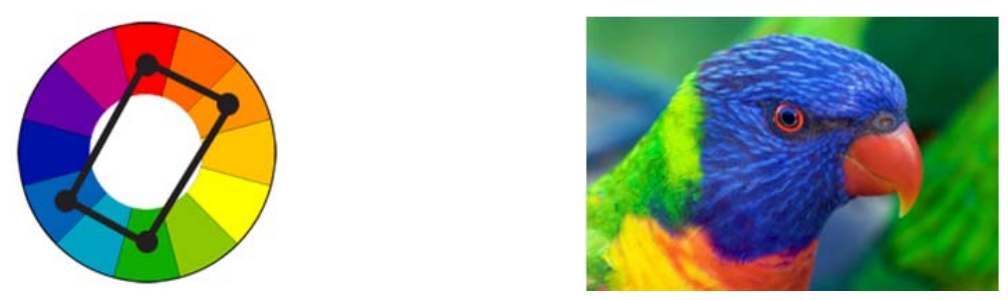

Figure 6 Rectangle (Tetradic) Color Scheme (TigerColor, 2016)

Last, square color scheme is similar to the rectangle one, but with all four colors spaced evenly around the color circle. Square color schemes work well when one color is set to be dominant (Figure 7). More attention should be made to the balance between warm and cool colors in the design. In addition, it is also necessary to learn how the psychological effects of color on people. Yogananti (2015) made conclusion of how colors affect people (Table 1). 

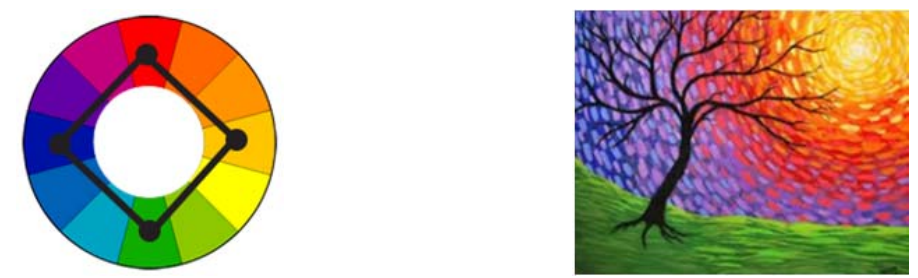

Figure 7 Square Color Scheme (TigerColor, 2016)

Table 1 Color Effect on Human Emotion

\begin{tabular}{clll}
\hline No & \multicolumn{1}{c}{ Color } & \multicolumn{1}{c}{ Impression } & \multicolumn{1}{c}{ Effect } \\
\hline 1. & Yellow & Rapid, Cheerful & Become joyful \\
2. & Yellow - Red & High passion, Annoy & \\
3. & Red - Yellow & Warm, Excitement & \\
4. & Blue & Joyful color & Become sad \\
5. & Red - Blue & Active & \\
6. & Red - Blue & & \\
7. & Red & Dignified & Come up spirit \\
8. & Green & Calm, Natural & Bring peace \\
\hline
\end{tabular}

Besides images and animations, audio is also necessary to support good audio-visual content (Liu, 2014; Yuliantu \& Layona, 2015). According Hidayanti (2011), learning by using songs and games are easier for children. To determine the right type of music for children Educational Games, the type of music that should be used is the music that appeals to kids. According to LeBlanc, music preferences that children like depend on the tempo (LeBlanc \& McCrary, 1983). Rarely, children's favorite songs have slow tempo. Leblanc's research used jazz music in around 1980. Because the music used is contemporary in his time, this study did not use music, but replace it with an instrumental children song.

The use of audio as supporting media in learning described by Linek demonstrated that background music has positive effect on intrinsic motivation and flow experience of the game (Linek, 2014). However, the use of background music in Linek's study showed no significant increase in learning outcomes, because the data structure of the study had a low level of learning. Overall, their findings provide evidence that background music does not interfere in learning. Background music can be considered as a source of motivation in educational games without damaging the success in learning (Rickard et al., 2010; Whalen, 2004).

The research problem is what audio visual should be implemented to improve elementary students' skill in mathematics. The objective of this research is to design and develop an educational game that implements the contents of audio visual which is the tempo of music, colors, and animation. The game will be applied for elementary students in learning mathematics. Hopefully, this educational game will make them interested in using it and improve their motivation in learning mathematics.

\section{METHODS}

Because of the nature of the aim of the current study, the data needed in this case consists of 4 types. First, in the stakeholder pre-development input data phase, research team will give the first concept from the game that will be created. The concept consist of game design, game material, and 
the mechanics of game. Second, in the development team input data phase, data is the complement from the previous deficiency that comes from main data. Development team will discuss to decide what elements that can be improved and what elements that need to be considered from the data that is provided by stakeholder. Third, in game tester input data phase, data will also be collected from respondents using questionnaires. In this case are elementary school students and teachers. While game development entered in prototyping step, it will be given to respondents to test the game's performance. Last, in stakeholder post-development input data phase, stakeholder will get $90 \%$ improvement of the game. Before finishing, stakeholder will check and test the game and giving the last feedback that will be implemented in the game.

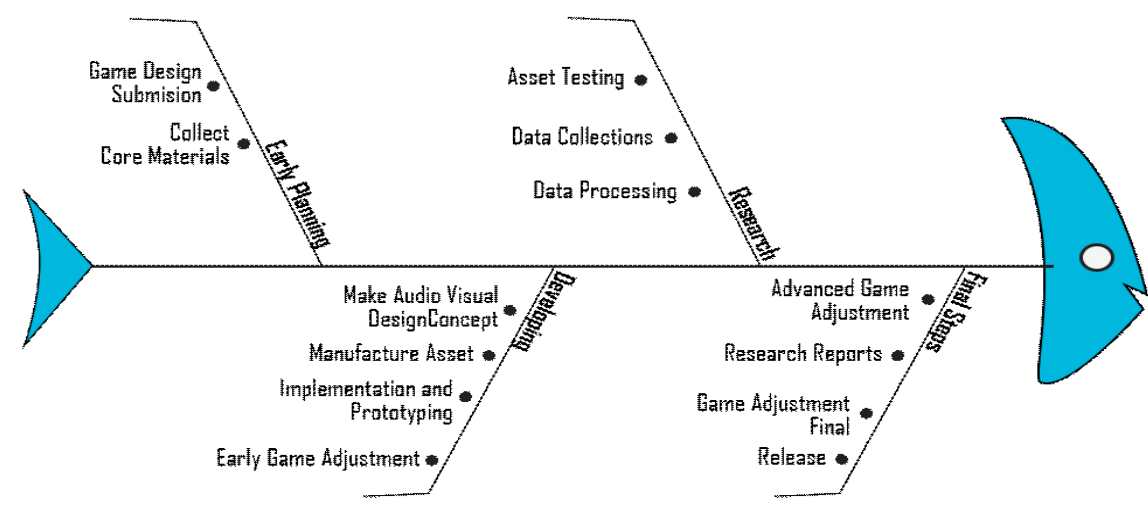

Figure 8 Fishbone Diagram

Overall, the steps of the research are described below and can be seen in Fishbone Diagram on Figure 8. In first step, the ideas of design and research proposal are discussed. Application entering development process started from beginning until it becomes a prototype in development phase. After that, application is ready to be tested. The obtained data can be processed to confirm the research hypothesis. In final step, the result of research can be concluded and implemented to contents of audio visual that will be developed.

Development method of audio visual are using Multimedia Development Life Cycle (MDLC). Requirement phase will determine the objective and requirement of creating the contents of audio visual based on literature review. Design phase will display the concept of audio visual that will be created based on requirement stage. Development phase is creating audio visual contents based on specification from design stage. Next, testing phase will test the contents whether it is necessary to meet the requirement or not. If not, it will be evaluated again in the requirement stage. Implementation phase will the final stage that implement the final contents to the game. In this stage, the evaluation and conclusion are also conducted, as shown in Figure 9.

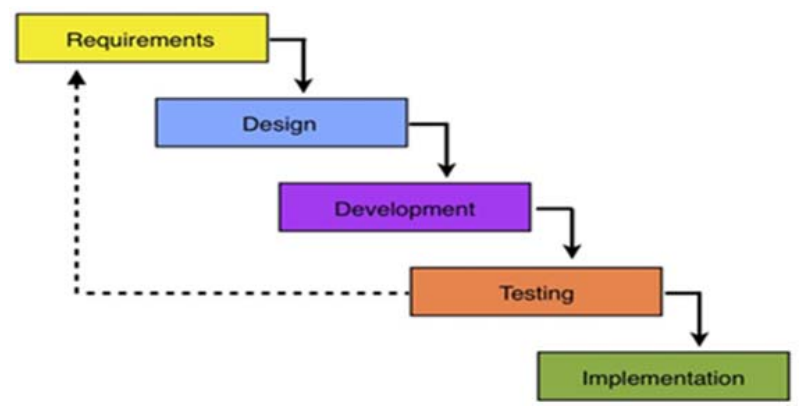

Figure 9 Multimedia Development Life Cycle 


\section{RESULTS AND DISCUSSIONS}

The following explanation is the research's discussion about audio visual content that is made to support the development of educational game. According to the literature that support the objective of the research to motivate the children to learn. It was determined some of aspect that will discussed in audio such as the tempo of music and type of songs that are liked by children. In addition to songs, it also discusses graphic, colors, and interactive animation that are liked by children.

Tested music is based on tempo. Hence, "Naik Becak" song (Figure 10) is chosen in this case, because the developing educational game that will be combined with this music is needed by children. Moreover, children songs tend to have some positive vibes that might be beneficial for children. Based on research of Hidayanti (2011) about the use of songs and games, instrument song of "Naik Becak" is made by using tones displayed in Figure 11.

Questionnaire distributed to first grade primary school students in SDN Palmerah 17 Pagi. Research instrument used instrumental music from "Naik Becak" song which was made into two types. First, it is $80 \mathrm{bpm}$ (beat per minute) and the second is $100 \mathrm{bpm}$ (normal tempo). 88\% respondents preferred $100 \mathrm{bpm}$ (normal tempo).

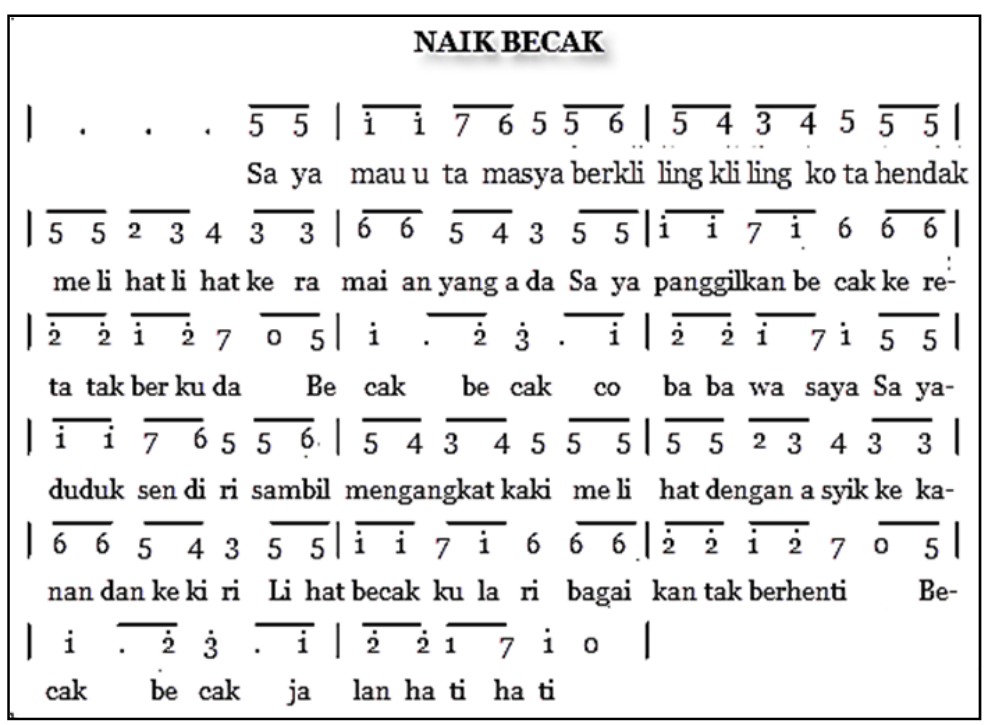

Figure 10 Scores of “Naik Becak” Song

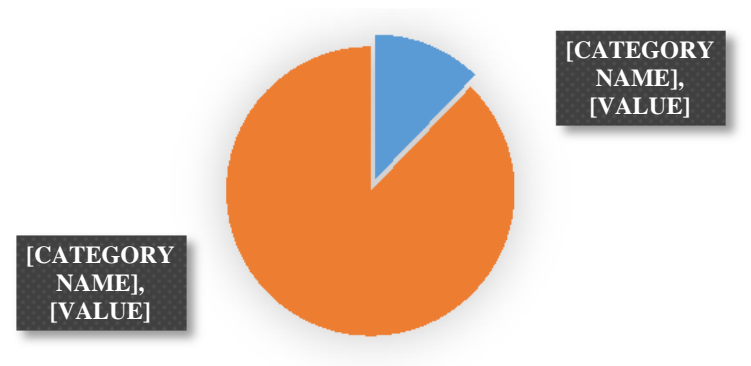

Figure 11 Tempo of Preferred Song 
Some sample images and animations have been created based on the theories that have been presented in the literature review about color and animation. Here are some animated graphics used for educational games (Figure 12).
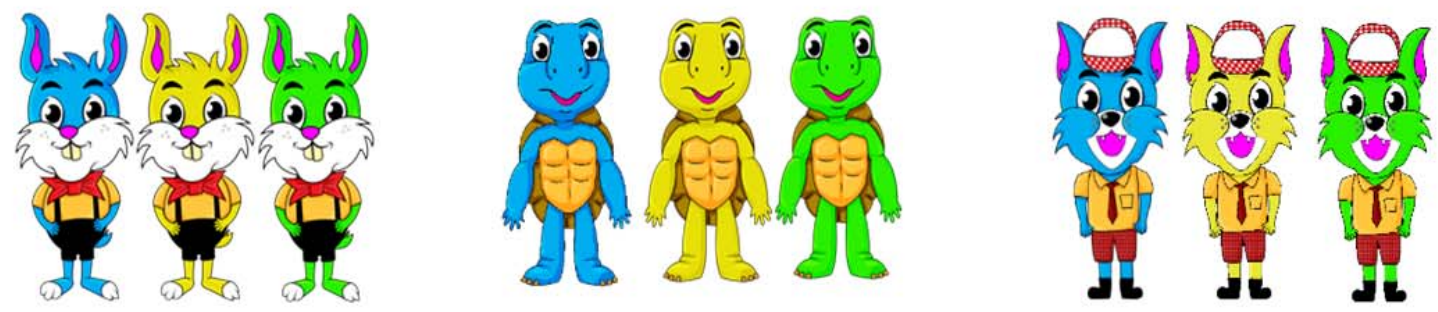

Figure 12 Character Used for Educational Games (Rabbit, Turtle, and Cat)

Each of these character then formed into moving animations which is also asked in the questionnaire for its color trends that appeal to children. The characters were made in various shapes and positions such as silent, waving hands, moving at the background of the game's main menu, and in the game position. Table 2 shows that rabbits are the most preferred character chosen by children $(45 \%)$, followed by turtle character (34\%). Figure 13 also shows the preference of animal character chosen by children.

Table 2 Questionnaire Result of Animal Type

\begin{tabular}{clc}
\hline No & Animal & Frequency \\
\hline 1. & Rabbit & 20 \\
2. & Turtle & 13 \\
3. & Cat & 8 \\
\hline
\end{tabular}

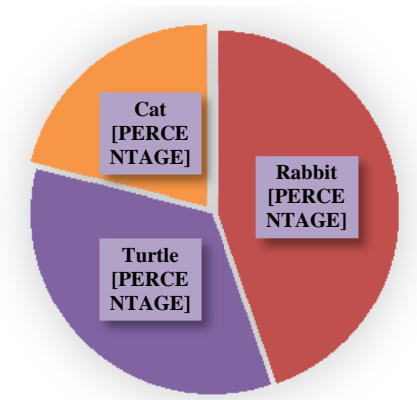

Figure 13 Animal Character Preferred by Students

Furthermore, the students are also asked preferences of the characters' color. Table 3 shows that most students preferred blue (46\%) and green (32\%), also it is presented in Figure 14.

Table 3 Questionnaire result of children favorite color

\begin{tabular}{clcc}
\hline No & Color & Frequency & Percentage \\
\hline 1. & Yellow & 9 & $22 \%$ \\
2. & Blue & 19 & $46 \%$ \\
3. & Green & 13 & $32 \%$ \\
\hline
\end{tabular}




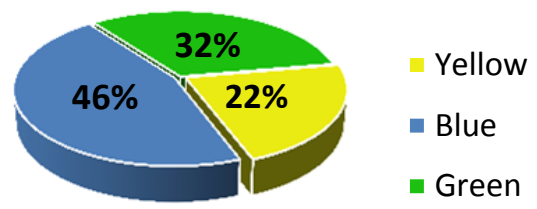

Figure 14 Preferred Characters’ Color
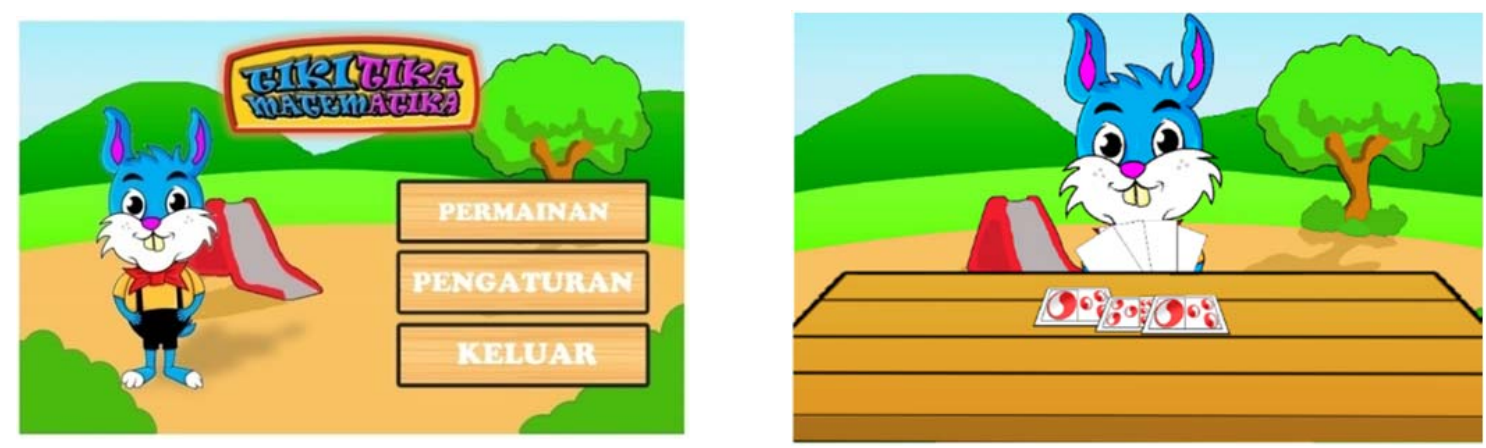

Figure 15 Screenshot of the Educational Games Using This Audio Visual Content

The graphics that showed in Figure 15 seemed to have friendly and fun characteristic. The smile of the character to show the player that this game is funny and friendly. Moreover, the color that is used for buttons, background, or font of the text are bright color that to give message to player that this game is for all age especially for children. Music that played in the Figure 15 will be music with fast tempo. Furthermore, to be more attractive, the character in the game will has voice actor. Also, there are more musical instruments such as brass, strings, piano, organ, or violin and played in major scale.

\section{CONCLUSIONS}

Based on the current research, it can be concluded that the interests and preferences of children tend to be towards something fun and active. The conclusion can be summed from children's interest at upbeat music, cheerful animation, and carefree colour like blue. With regards to the developed game, children tend to be happier and more comfortable to view moving images, with cute graphics, and pleasant color. Children also showed to love the type of music that is made for children with a low level of difficulty tone, faster tempo, and attractive. If the children are interested in animated graphics and music, these will affect the child's desire to play and might even have increased eagerness to learn. Therefore, educational game that provides any interactive content of audio-visual can be a better alternative method for learning. 


\section{REFERENCES}

Abdullah, M., Bakar, Z., Ali, R., \& Faye, I. (2011). Video Games in Children's Learning of Mathematics. International Journal of Basic \& Applied Sciences, 11(2), 14-17.

Ameliola, S., \& Nugraha, D. H. (2013). Perkembangan Media Informasi dan Teknologi Terhadap anak dalam Era Global. The 5th International Conference on Indonesian Studies: Ethnicity and Globalization, 362-371.

Amirali, M. (2010). Students' Conceptions of the Nature of Mathematics and Attitudes Towards Mathematics Learning. Journal of Research and Reflections in Education, 4(1), 27-41.

Arsyad, A. (2007). Media Pembelajaran. Jakarta: PT. Raja Grafindo Persada.

Chiong, C., \& Shuler, C. (2010). Learning: Is There an App for That: Investigations of Young Children's Usage and Learning with Mobile Devices and Apps. New York: The Joan Ganz Cooney Center.

Fisch, S. M. (2005). Making Educational Computer Games "Educational". The 2005 Conference on Interaction design and children, 56-61. doi: 10.1145/1109540.1109548

Goethe, J. W. V. (1840). Theory of Colours. London: MIT Press.

Hamdani. (2011). Strategi Belajar Mengajar. Bandung: CV. Pustaka Setia.

Haryoko, S. (2012). Efektivitas Pemanfaatan Media Audio-Visual Sebagai Alternatif Optimalisasi Model Pembelajaran. Jurnal Edukasi Elektro, 5(1). 1-10.

Hidayanti, F. (2011). Peningkatan Keterampilan Berbicara Bahasa Inggris Melalui Lagu dan Permainan pada Siswa Kelas IV Di SDN Madiredo 02 Kecamatan Pujon Kabupaten Malang (Undergraduate Thesis). Universitas Negeri Malang.

LeBlanc, A., \& McCrary, J. (1983). Effect of Tempo on Children's Music Preference. Journal of Research in Music Education, 31(4), 283-294. doi: 10.2307/3344631

Linek, S., Marte, B. \& Albert, D. (2014). Background Music in Educational Games: Motivational Appeal and Cognitive Impact. International Journal of Game-Based Learning, 1(3), 53-64. doi: 10.4018/978-1-4666-5071-8.ch016

Liu, E. M. (2014). Motivating Students to Learn Using A Game-Based Learning Approach: Gaming and Education Issue. Texas Education Review, 2(1), 117-128.

Mayer, R. E., \& Moreno, R. (2002). Animation as an Aid to Multimedia Learning. Educational Psychology Review, 14, 87-99.

Rakhmawati, E. (2014). Pengaruh Metode Bermain Kreatif Terhadap Prestasi Belajar Matematika Anak Sekolah Dasar. Malih Peddas, 2(2).

Rickard, N. S., Vasquez, J. T., Murphy, F., Gill, A., \& Toukhsati, S. R. (2010). Benefits of a Classroom based Instrumental Music Program on Verbal Memory of Primary School Children: a Longitudinal Study. Australian Journal of Music Education, (1), 36-47. 
Rideout, V., Lauricella, A., \& Wartella, E. (2011). Children, Media, and Race: Media Use Among White, Black, Hispanic, and Asian American Children. Evanston: Northwestern University.

Suheri, A. (2006). Animasi Multimedia Pembelajaran. Jurnal Media Teknologi, 2(1), 27-33.

TigerColor. (2016). Basic Color Schemes - Introduction to Color Theory. Retrieved April $4^{\text {th }} 2016$ from http://www.tigercolor.com/color-lab/color-theory/color-theory-intro.htm

Utami, D. (2011). Animasi Dalam Pembelajaran. Majalah Ilmiah Pembelajaran, 7(1), 44-52.

Whalen, Z. (2004). Play Along-An Approach to Videogame Music. Game studies, 4(1).

Yien, J. M. (2011). A Game-Based Learning Approach to Improving Students' Learning Achieveents in A Nutrition Course. TOJET: The Turkish Online Journal of Educational Technology, 10(2), $1-10$.

Yogananti, A. F. (2015). Pengaruh Psikologi Kombinasi Warna Dalam Website. Jurnal Desain Komunikasi Visual \& Multimedia, 1(1), 45-54.

Yulianto. B., Heriyanni, E., Sembiring, R., E., Amalia, R., \& Fridian, R. (2013). Aplikasi Pembelajaran Algoritma Dasar Interaktif Berbasiskan Computer Assisted Instruction. ComTech, 4 (2), 1255-1266.

Yuliantu, B., \& Layona, R. (2015). Penerapan Computer Assisted Instruction (CAI) Untuk Membantu Guru Sekolah Dasar Dalam Mengajar Kebudayaan Indonesia. Jurnal Teknik \& Ilmu Komputer, 4(14), 201-210. 